\title{
Terminal deletion (14)(q32.3): a new case
}

\author{
N Telford, D A G Thomson, M J Griffiths, S Ilett, J L Watt
}

\begin{abstract}
A mildly dysmorphic, 2 year old girl with mental retardation was found to have a small de novo terminal deletion of the long arm of chromosome 14, del(14)(q32.3). She was found to have features in common with two previous terminal deletion cases and particularly with the well documented ring 14 syndrome, although seizures, a characteristic feature of ring 14, were notably absent.
\end{abstract}

More than 30 cases of ring chromosome 14, associated with terminal monosomy $14 \mathrm{q}$, have been reported, most recently by Howard et al. This is now recognised as a distinct syndrome. ${ }^{2}{ }^{3}$ There are only two previous reports of distal monosomy $14 \mathrm{q}$ without ring formation or other chromosome rearrangement, $\operatorname{del}(14)(\mathrm{q} 32.3)^{4}$ and $\operatorname{del}(14)(\mathrm{q} 31.1) .{ }^{5}$ We present a further case and compare it with previous reports.

\section{Case report}

A Caucasian girl, aged 2 years 2 months, was referred for examination with delayed mental development and a mildly dysmorphic appearance (fig 1). She was born at term, with a birth weight of $3460 \mathrm{~g}$, after a forceps delivery because of a delay in the second stage of labour. The baby's mother and father were healthy, non-consanguineous, and aged 27 and 31 years, respectively. The mother was admitted to hospital during this, her only pregnancy, because of poor fetal movements. During the neonatal period, the baby was floppy and had mild jaundice and a slow feeding problem, which were both quickly corrected.

The current examination showed the patient to have an oval face with a prominent forehead, dolichocephaly, and a flat occiput. There was a broad,

Regional Cytogenetics Unit, Birmingham Maternity Hospital, Edgbaston, Birmingham B15 2TG.

N Telford, D A G Thomson, M J Griffiths, J L Watt

Child Development Centre, The Children's Hospital, Ladywood Middleway, Ladywood, Birmingham B16 8ET. $S$ Ilett

Correspondence to Mr Griffiths.

Received for publication 20 June 1989.

Revised version accepted for publication 9 October 1989.

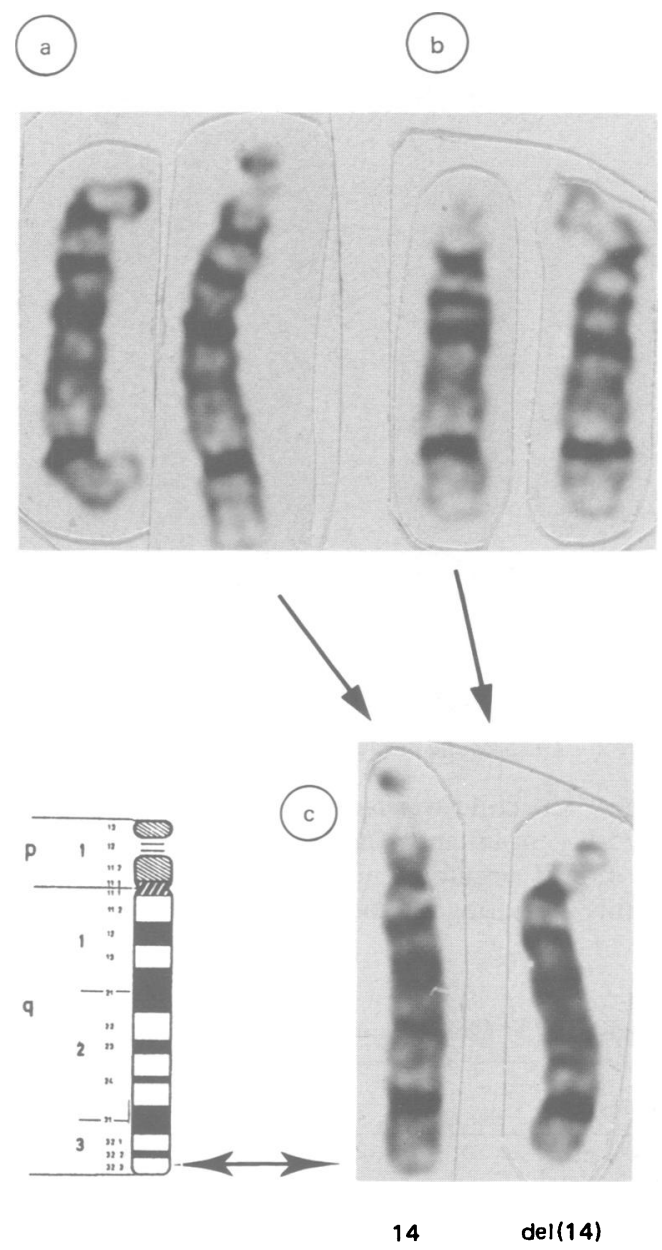

Figure $1 \quad G$ banded partial karyotypes showing chromosomes 14 of $(a)$ the father, (b) the mother, and (c) the proband (normal chromosome 14 left, deleted chromosome 14 right) with arrows to indicate the breakpoint and the suggested inheritance by satellite polymorphism.

flattened nasal bridge, slightly anteverted nostrils, and a fish shaped mouth with a high arched palate. The vision was normal, but the eyes were slightly downward slanting, with ptosis and epicanthic folds. The formation and position of the ears were normal, but there was a minimal hearing loss probably owing to middle ear fluid. She also had short, chubby 


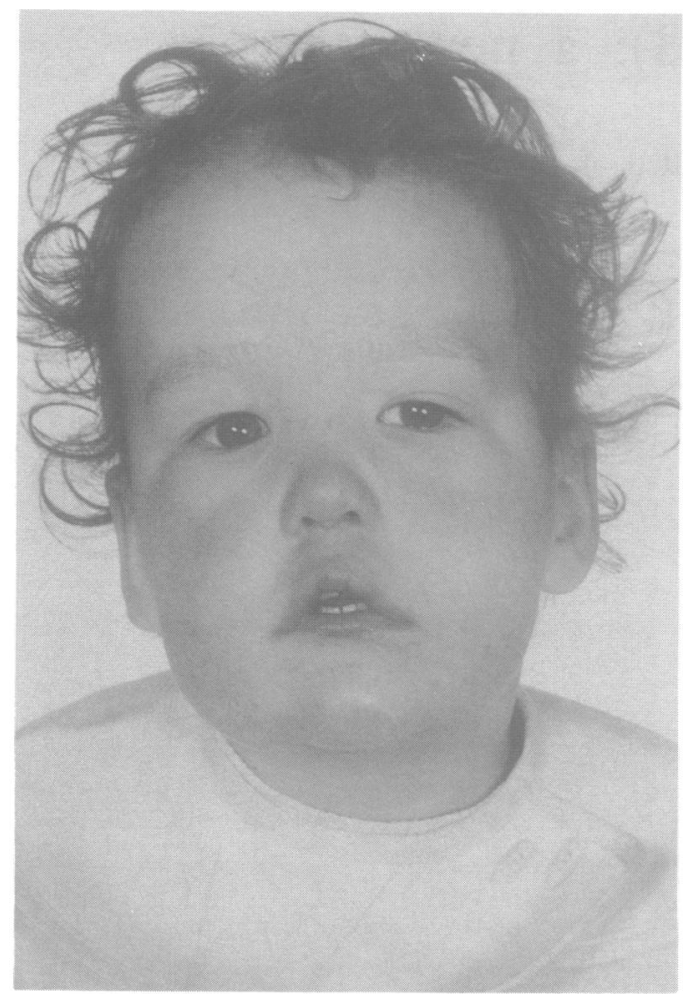

Figure 2 The proband aged 2 years 5 months.

fingers. The child was large for her age, weight 13.65 $\mathrm{kg}$ (75th centile) and length $91 \mathrm{~cm}$ (75th centile) yet with a head circumference of $47.5 \mathrm{~cm}$ (25th centile), possibly indicating microcephaly. She had generalised, mild hypotonia, marked hypotonia of the legs and pelvis, and was hyporeflexic. The patient also had a moderate deficit in mental ability with play, attention control, social skills, and comprehension at a 14 month age level. Language expression was confined to immature babbling and was below a 12 month age level.

In contrast to previous findings in $14 \mathrm{q}$ deletion and ring 14 cases, there was no apparent cardiac defect, no skin dyspigmentation, and no history of seizures or recurrent respiratory infections.

\section{CYTOGENETICS}

Thymidine synchronised peripheral blood lymphocyte cultures were used to produce metaphase chromosomes which were $G$ banded using a standard (GTL) technique.

The patient had a karyotype 46,XX,del(14)(q32.3). Both mother and father had apparently normal karyotypes and so the proband has a de novo deletion. The appearance of satellite polymorphisms in the G banded preparations suggests that the abnormal chromosome 14 is maternal in origin (fig 2).

\section{Discussion}

The present case has dysmorphic features and mental retardation in common with previous $14 \mathrm{q}$ terminal deletion and ring 14 cases, although the above average size and weight of our patient are not consistent with previous findings (table). The deletion 14q32.3-qter

A comparison of features in the present case with previous cases of distal monosomy $14 q$.

\begin{tabular}{|c|c|c|c|c|}
\hline Features & $\begin{array}{l}\text { Present } \\
\text { case }\end{array}$ & $\begin{array}{l}\text { Yen } \\
\text { et } a l^{5}\end{array}$ & $\begin{array}{l}\text { Hreidarsson and } \\
\text { Stamberg }^{4}\end{array}$ & $\begin{array}{l}\text { Ring } 14 \\
\text { syndrome }\end{array}$ \\
\hline Breakpoints & $14 \mathrm{q} 32.3$ & $14 \mathrm{q} 31.1$ & $14 \mathrm{q} 32.3$ & \\
\hline High forehead & + & $?$ & + & + \\
\hline Dolichocephaly & + & $?$ & + & + \\
\hline Microcephaly & + & + & - & + \\
\hline Flat occiput & + & $?$ & $?$ & + \\
\hline Downward slanting eyes & + & $?$ & - & + \\
\hline Epicanthic folds & + & + & - & + \\
\hline Broad/flat nasal bridge & + & - & + & + \\
\hline Anteverted nostrils & + & - & - & + \\
\hline Broad philtrum & + & + & + & + \\
\hline Down turned mouth & + & $?$ & $?$ & + \\
\hline High arched/narrow palate & + & + & + & + \\
\hline Micrognathia & - & + & + & + \\
\hline Low set ears & - & - & - & + \\
\hline Malformed ears & - & + & + & ? \\
\hline Short neck & - & - & - & + \\
\hline Strabismus & - & + & - & + \\
\hline Seizures & - & - & - & + \\
\hline Hypotonia & + & + & - & + \\
\hline Mental retardation & + & + & + & + \\
\hline Congenital heart disease & - & - & + & \pm \\
\hline Respiratory infections & - & - & - & + \\
\hline Dyspigmentation & - & - & - & \pm \\
\hline
\end{tabular}


seems to be responsible for many of the features associated with the ring 14 syndrome; however, some features of ring 14, most notably seizures, are absent from our patient. Indeed, the three reported $14 \mathrm{q}$ terminal deletion cases had no history of seizures, whereas all 25 ring 14 patients reviewed by Gilgenkrantz et $a l^{3}$ had epileptic convulsions. This suggests, contrary to the assumption of Howard et al, ${ }^{1}$ that monosomy of band $14 \mathrm{q} 32.3$ is not responsible for seizures and that this effect is a consequence of the loss of more proximal genes, ring instability at mitosis, or a compound effect including the deletion.

There are many reports of the ring 14 syndrome, the majority having a breakpoint in $14 \mathrm{q} 32$, whereas there are only two reports of terminal deletions in this band. However, ring chromosomes are much easier to detect than the small deletion 14q32-qter. Therefore, there may well be some under-reporting of distal $14 \mathrm{q}$ monosomy, as first suggested by Hreidarsson and Stamberg. ${ }^{4}$ With the description of further cases of 14q terminal deletions, a clinical picture more specific than that for ring 14 syndrome should develop.

1 Howard PJ, Clark D, Dearlove J. Retinal/macular pigmentation in conjunction with ring 14 chromosome. Hum Genet 1988;80: $140-2$.

2 Schmidt R, Evitar L, Notowsky HM, Wong M, Miranda S. Ring chromosome 14: a distinct clinical entity. $\mathcal{F}$ Med Genet 1981;18:304-7.

3 Gilgenkrantz S, Morali A, Vidailhet M, et al. Le syndrome r(14). Trois nouvelles observations. Ann Genet (Paris) 1984;27:73-8.

4 Hreidarsson $S$, Stamberg J. Distal monosomy 14 not associated with ring formation. F Med Genet 1983;20:147-9.

5 Yen F, Podruch PE, Weisskopf B. A terminal deletion (14) (q31.1) in a child with microcephaly, narrow palate, gingival hypertrophy, protuberant ears, and mild mental retardation. f Med Genet 1989;26:130-3. 